\title{
Nuclear Behaviour and Spindle-pole Bodies During Ascosporogenesis in Peziza quelepidotia
}

\author{
By K. L. O'DONNELL, W. TAI AND E. S. BENEKE \\ Department of Botany and Plant Pathology, Michigan State University, \\ East Lansing, Michigan 48824, U.S.A.
}

(Received 26 March 1973; revised 30 August 1973)

\begin{abstract}
SUMMARY
The behaviour of nuclei and spindle-pole bodies in Peziza quelepidotia Korf \& O'Donnell, a homothallic Discomycete, was investigated by light microscopy from ontogeny of the crozier up to ascosporogenesis. All nuclear divisions appeared to be intranuclear. Plaque-shaped spindle-pole bodies were discernible during the synchronous mitotic division in the crozier, the reductional division in the ascus and the mitotic division preceding sporogenesis. The intranuclear reductional division was of the 'Neurospora type' with no time interval between karyogamy and the onset of meiosis. This type of meiosis is further characterized by the presence of highly contracted homologues at synapsis and the absence of leptotene. A comparison of the behaviour of spindle-pole bodies in this species with other members of the Euascomycetidae is presented.
\end{abstract}

\section{INTRODUCTION}

In recent years, ascosporogenesis in the Euascomycetidae has been investigated extensively at the light-microscopic level (Singleton, I953; Carr \& Olive, I958; Doguet, I960; Lu, 1967; Zickler, 1967; Beckett \& Wilson, I968) and ultrastructural level (Reeves, I967; Carroll, 1969; Wells, 1970; Zickler, 1970; Beckett \& Crawford, 1970). We made a light microscopical investigation of the behaviour of the nuclei and spindle-pole bodies (Aist \& Williams, 1972) during ascosporogenesis in the Discomycete Peziza quelepidotia Korf \& O’Donnell.

\section{METHODS}

Cultures of Peziza quelepidotia were grown in Petri dishes on a medium of Jiffy-7 pellet infusion agar (prepared by homogenizing three Jiffy-7 pellets per litre plus $20 \mathrm{~g}$ agar) at $25 \pm \mathrm{I}{ }^{\circ} \mathrm{C}$ with continuous white light supplied by fluorescent tubes. Apothecia in various stages of development were harvested and cut longitudinally into thin pieces. The fertile slices were immediately fixed in modified BAC fixative containing 9 parts ethanol, 6 parts propionic acid and 2 parts $10 \%$ aqueous chromic acid (Lu \& Raju, 1970) for $24 \mathrm{~h}$ at room temperature $\left(25 \pm \mathrm{I}{ }^{\circ} \mathrm{C}\right)$ and stored at 0 to $4{ }^{\circ} \mathrm{C}$ until examined cytologically. The hymenial pieces were hydrolysed in $\mathrm{N}-\mathrm{HCl}$ in a $65^{\circ} \mathrm{C}$ water bath for $20 \mathrm{~min}$. The acid was replaced with water and the tissue left at room temperature for at least 3 days. The tissue was further hydrolysed for $45 \mathrm{~min}$ in $\mathrm{N}-\mathrm{HCl}$ at $65{ }^{\circ} \mathrm{C}$ and the acid was decanted and replaced with $50 \%$ propionic acid. This solution was placed in a $65{ }^{\circ} \mathrm{C}$ water bath for $5 \mathrm{~min}$ and then immediately cooled in an ice bath. 


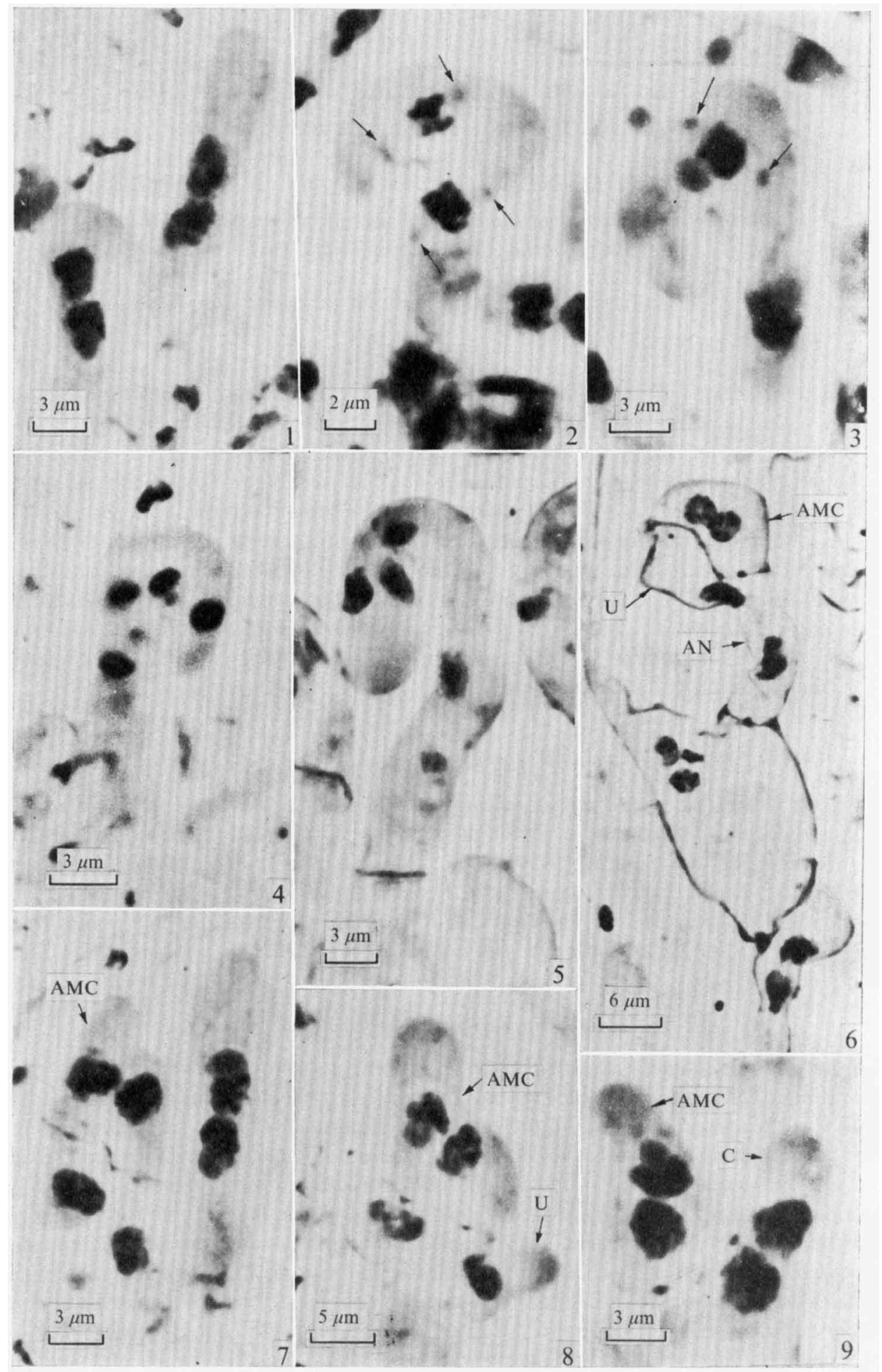


The stain employed was propionic iron haematoxylin (Lu, 1967; Lu \& Raju, 1970). A small piece of hymenium was placed on a glass slide in a drop of their solution ' $B$ ' and covered with another glass slide. The asci were spread out by pounding the top glass slide and then the slides were separated. A drop of solution ' $A$ ' was added to solution ' $B$ ' and the asci were further squashed under a coverslip. The slides were briefly heated over an alcohol lamp and then ringed with dental sticky wax.

All slides were examined and photographed with phase-contrast illumination on a Zeiss Photomicroscope II fitted with a Planapo I00/I 3 objective and an achromatic-aplanatic phase condenser (numerical aperture $=\mathrm{I} \cdot 4$ ). Photographs were taken with a built-in 35 mm camera on Kodak Panatomic-X film exposed at ASA 25 and developed in either Kodak D-76 (I:I) or Microdol-X (I:3). All prints were made on Kodak Kodabromide F-5 paper.

\section{RESULTS}

Ontogeny of a typical Dangeardian crozier (Fig. I) was initiated by the migration of two nuclei into a terminal ascogenous hypha. These nuclei underwent a synchronous mitotic division (Figs. 2 to 5), at which time plaque-like spindle-pole bodies (SPBs; Aist \& Williams, I972) were discernible. During this division, there was a marked decrease in the nucleolar size. The binucleate ascus mother cell was then delimited by septation (Fig. 6). As this penultimate cell elongated (Figs. 7 to 9) there was a concomitant proliferation of the ultimate cell. The antipenultimate cell nucleus then migrated into the ultimate cell where these nuclei underwent a synchronous mitotic division (Fig. I0).

Karyogamy took place shortly after the binucleate ascus mother cell (penultimate) began to extend (Figs. Io to I 2). At karyogamy the nucleoli were always situated at opposite ends of the respective nuclei (Fig. I I). In the late zygotene to early pachytene nucleus (Fig. I3) the nucleoli had fused, forming a large crescent-shaped nucleolus. Relational coiling of some homologues was discernible at full pachytene (Fig. I4). At early diplotene, the chromosomes became more extended and the homologous chromosomes began to separate (Fig. I5). Two lightly staining amorphous bodies were discernible on the nuclear membrane at this stage and may have represented replicated SPBs or nuclear blebs. As the homologues continued to separate, the meiotic nucleus entered the diffuse diplotene stage (Fig. I6). There was no apparent decrease in the size of the nucleolus at this stage. Inability to find diakinesis suggests that this stage was relatively short in this fungus. At metaphase I, the bivalents lined up forming a distinct equatorial plate (Fig. I7). The presence of a distinct meiotic metaphase plate is an uncommon feature in the fungi (Olive, 1965). The intranuclear

Unlabelled arrows are used to locate the spindle-pole bodies. Lengths of scale bars are approximate.

Fig. I. Nuclear migration into Dangeardian crozier (left cell).

Fig. 2. Synchronous mitotic metaphase in crozier.

Fig. 3. Mitotic metaphase in crozier.

Fig. 4. Mitotic telophase in crozier.

Fig. 5. Interphase following synchronous mitosis in crozier.

Fig. 6. Binucleate ascus mother cell (AMC) subtended by ultimate (U) and antipenultimate (AN) cells.

Fig. 7. Elongation of binucleate ascus mother cell (AMC).

Fig. 8. Binucleate ascus mother cell (AMC) subtended by extending ultimate cell (U).

Fig. 9. Binucleate ascus mother cell (AMC) subtended by binucleate crozier (C). 


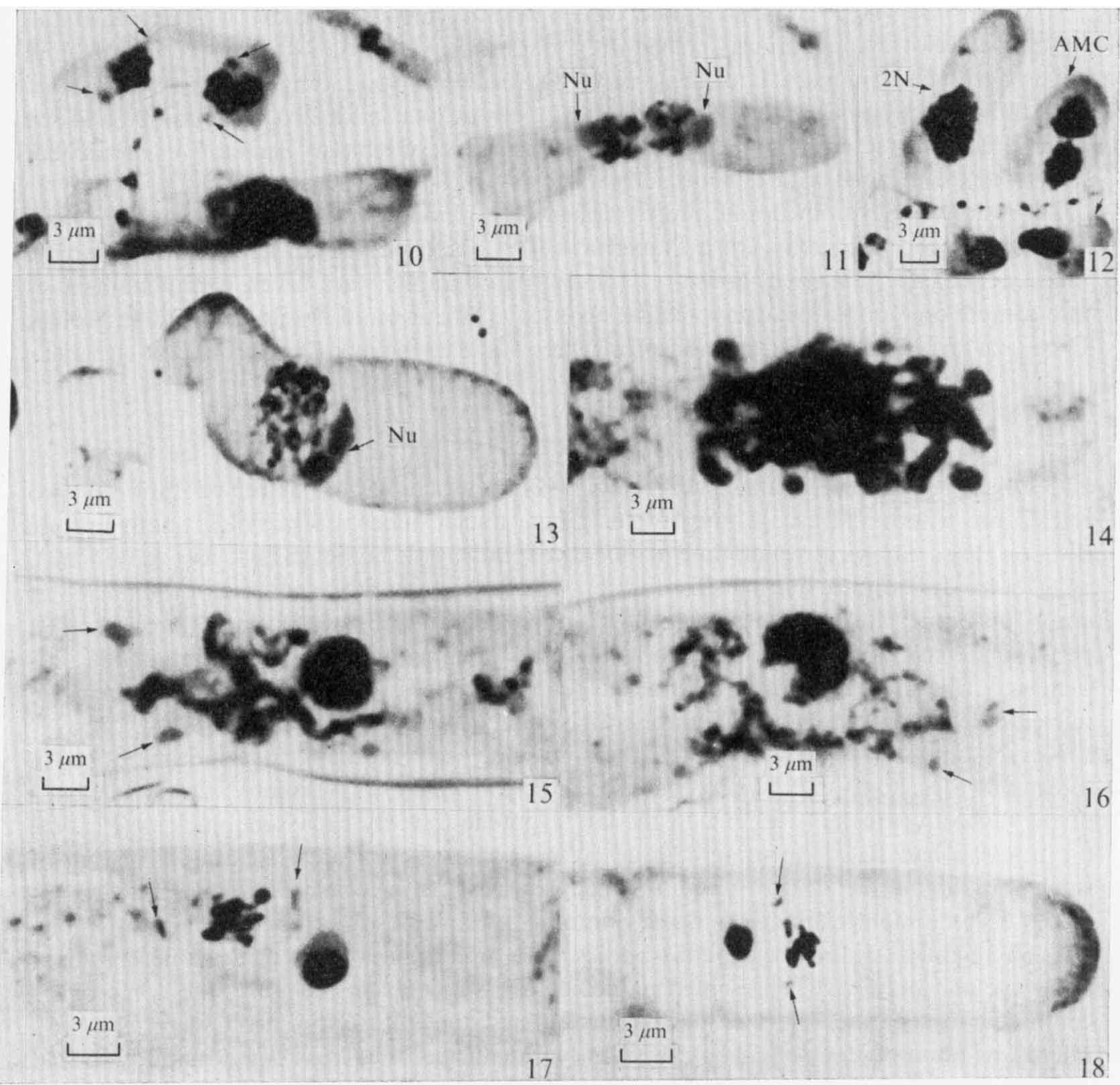

Unlabelled arrows are used to locate the spindle-pole bodies. Lengths of scale bars are approximate.

Fig. Io. Synchronous mitotic metaphase in crozier subtending a young diploid ascus.

Fig. II. Karyogamy in a young ascus. Arrows locate the nucleoli (Nu).

Fig. I2. Binucleate ascus mother cell (AMC) and young diploid ascus $(2 \mathrm{~N})$ subtended by ultimate cell (U).

Fig. 13. Late zygotene to early pachytene nucleus with a crescent-shaped nucleolus $(\mathrm{Nu})$.

Fig. 14. Full pachytene with relational coiling of some homologues.

Fig. 15. Diplotene with two amorphous bodies (SPBs or nuclear blebs?) contiguous with the nuclear membrane.

Fig. I6. Diffuse diplotene with extended homologues and two amorphous bodies (SPBs or nuclear blebs?) contiguous with the nuclear membrane.

Fig. 17. Metaphase I with intranuclear spindles and plaque-like SPBs at the poles.

Fig. I8. Metaphase I with spindles perpendicular to the long axes of the ascus. 


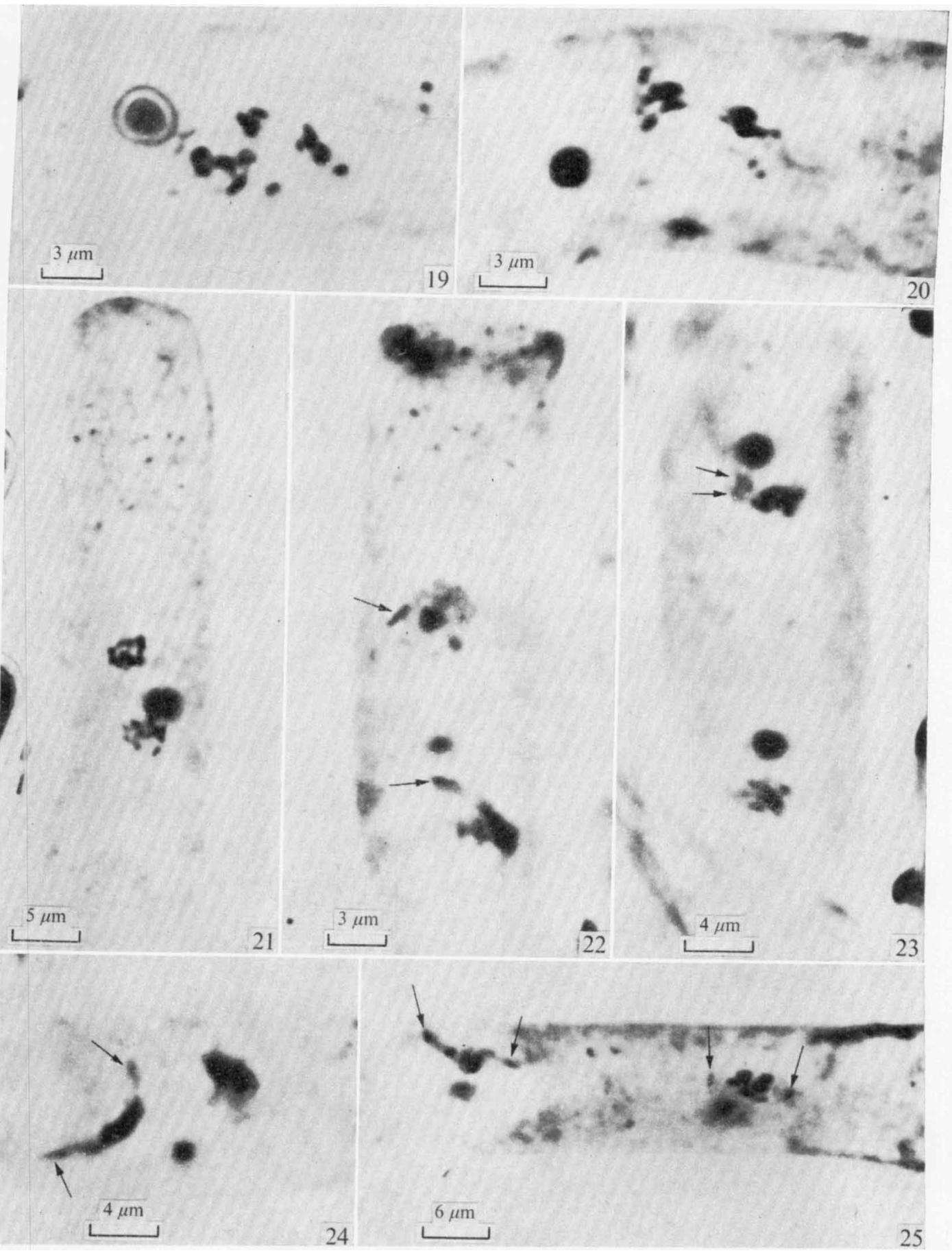

Unlabelled arrows are used to locate the spindle-pole bodies. Lengths of scale bars are approximate.

Fig. 19. Metaphase I with 14 to 15 bivalents.

Fig. 20. Anaphase I with continuous spindle fibres.

Fig. 2I. Telophase I with regrouped chromosomes at the poles.

Fig. 22. Interphase I with a plaque-like SPB on each nucleus.

Fig. 23. Prometaphase II with replicated SPBs.

Fig. 24. Prometaphase II with SPBs migrating to the poles.

Fig. 25. Metaphase II with polar SPBs and chromosomes on distinct equatorial plates. 


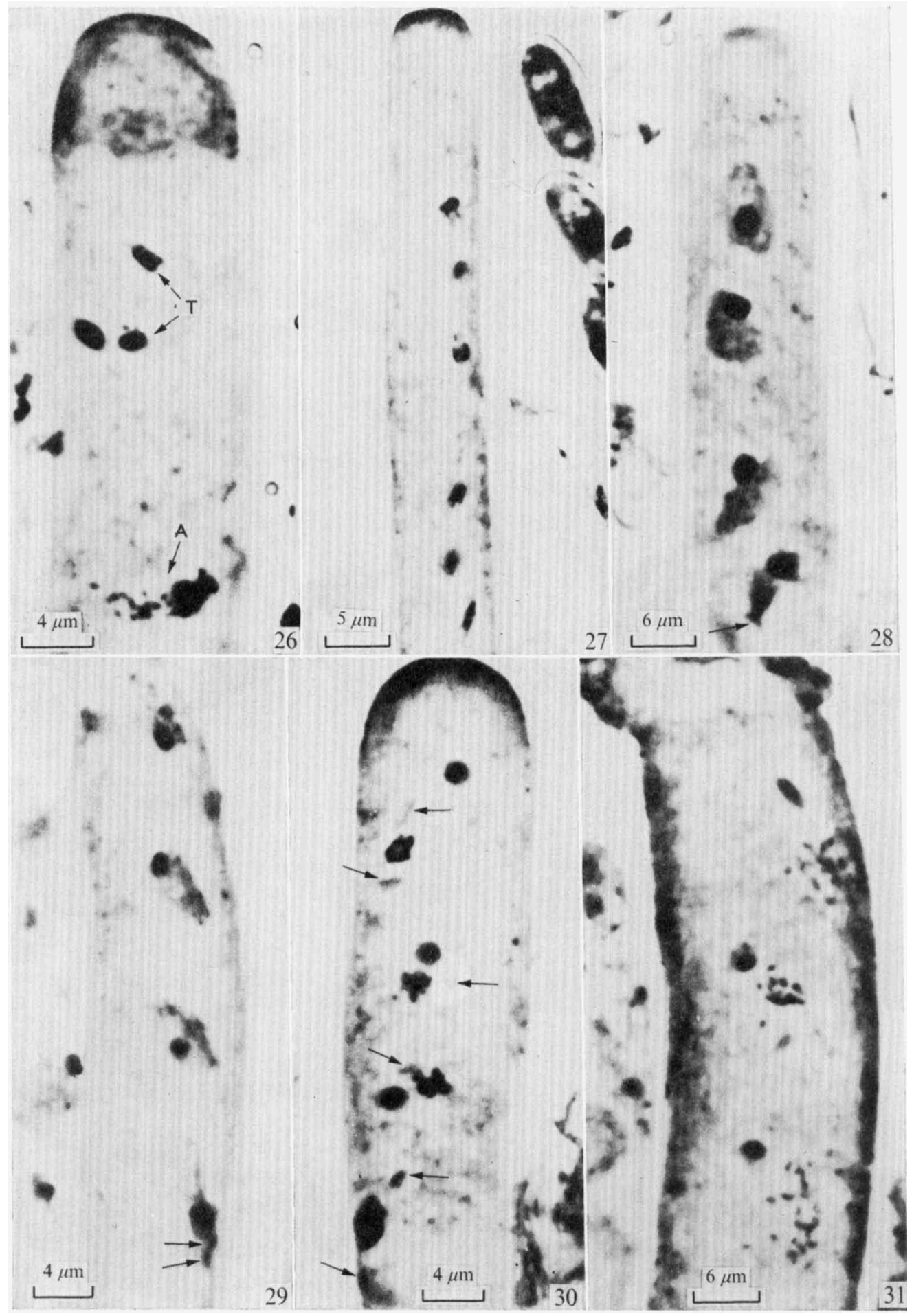

Unlabelled arrows are used to locate the spindle-pole bodies. Lengths of scale bars are approximate. Fig. 26. Anaphase (A) and telophase II (T) showing asynchronous anaphase movements in adjacent nuclei.

Fig. 27. Telophase II with linearly arranged nuclei.

Fig. 28. Interphase II with SPB visible on one nucleus.

Fig. 29. Prophase III with replicated SPBs.

Fig. 30. Mitotic metaphase III with plaque-like SPBs at the spindle poles.

Fig. 3I. Mitotic anaphase III showing three of the four spindles. 


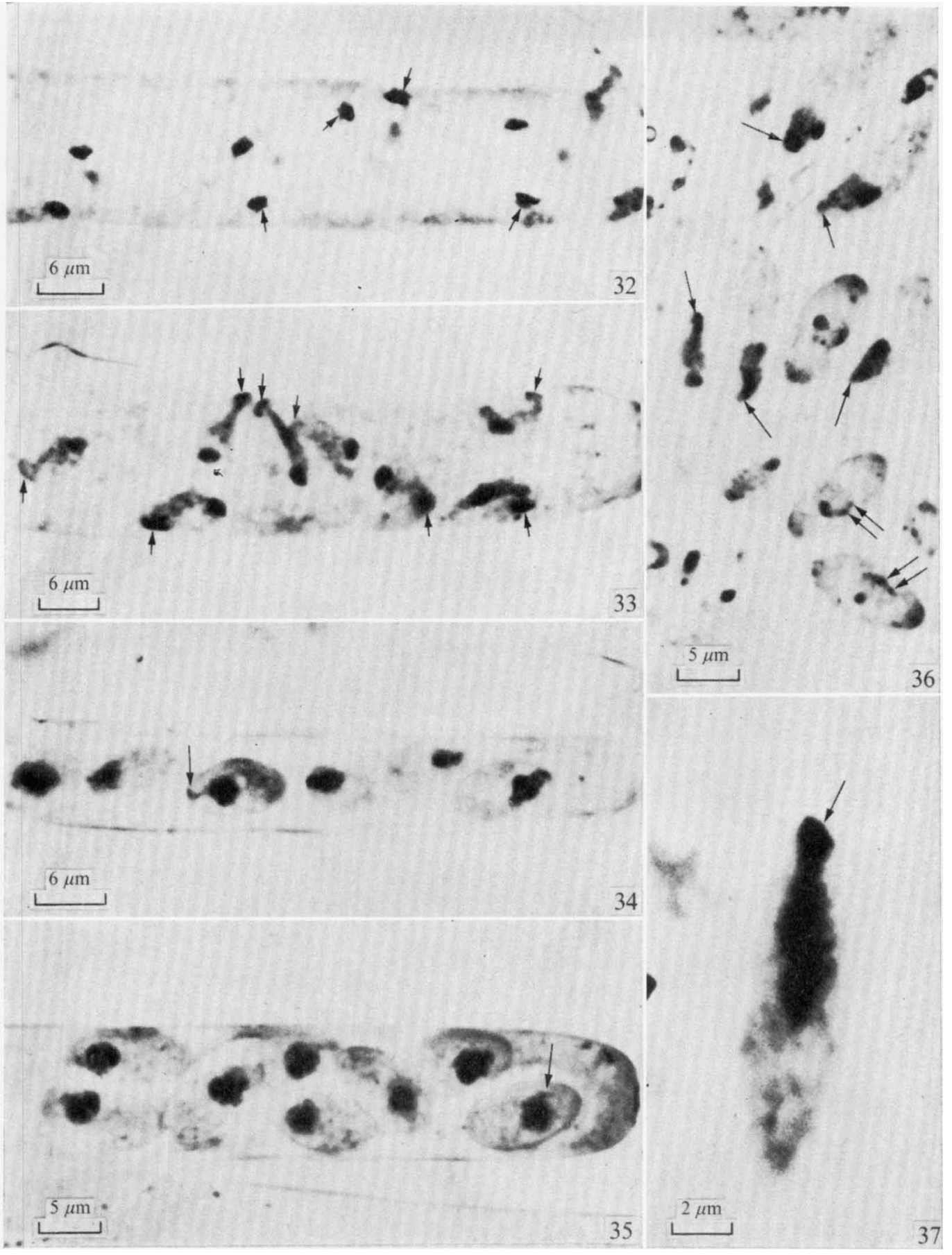

Unlabelled arrows are used to locate the spindle-pole bodies. Lengths of scale bars are approximate.

Fig. 32. Mitotic telophase III with SPBs visible on some of the nuclei.

Fig. 33. Interphase III (the beaked nuclear stage) with greatly enlarged crescent-shaped SPBs.

Fig. 34. Spore delimitation showing a SPB near one end of a developing ascospore.

Fig. 35. Spore delimitation showing retraction of a SPB from the developing spore wall.

Fig. 36. Various stages of spore delimitation showing the SPB near one end of the spore initials. Note that two dark-staining bodies (SPB?) appear on the nuclear membrane of nuclei that have retracted from the spore wall.

Fig. 37. Spore initial with SPB near one end of developing spore wall. 


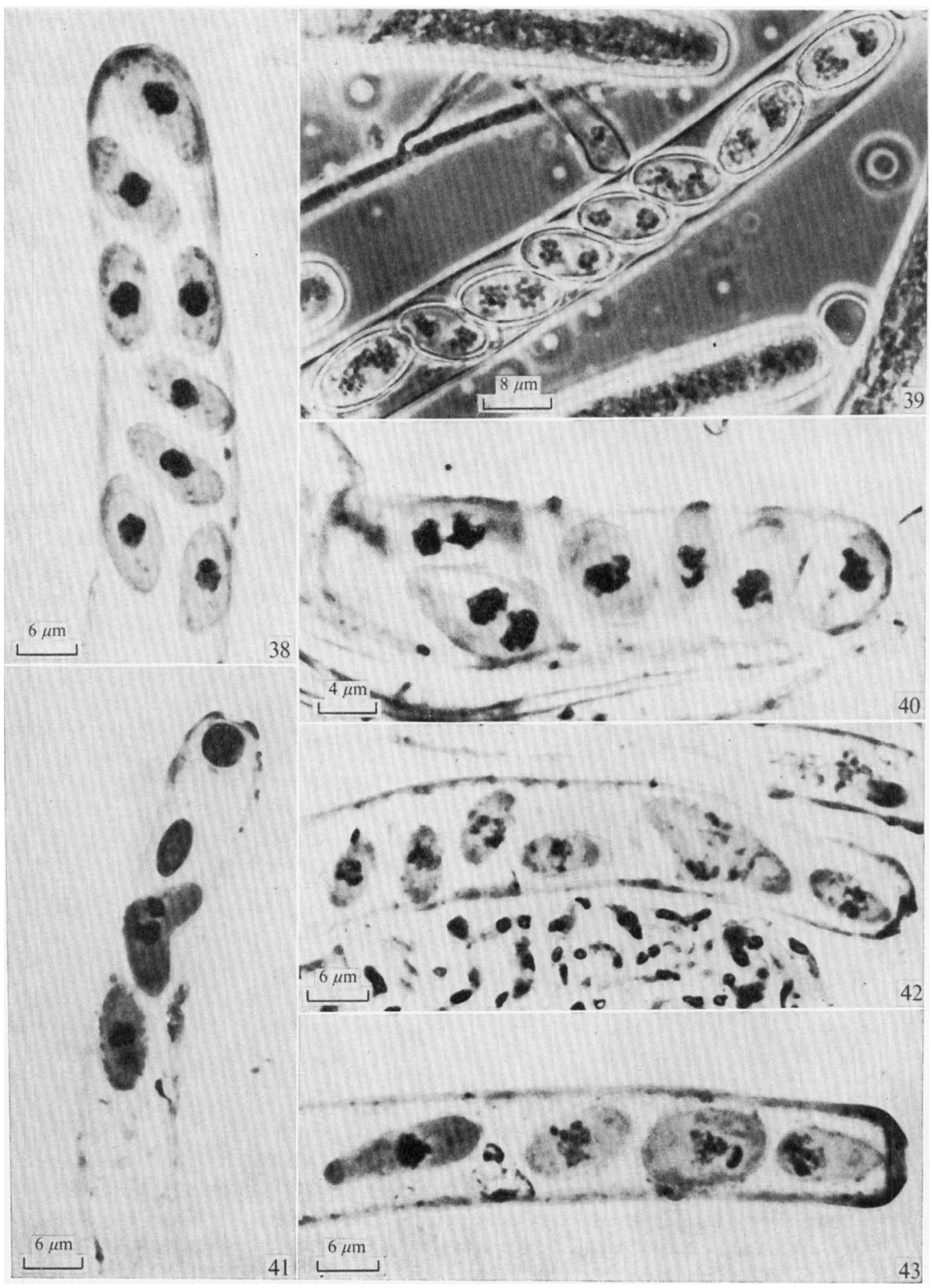


spindle at metaphase I was typically found to be parallel to the long axis of the ascus but occasionally a perpendicular arrangement was seen (Fig. I8). In favourable squashes of metaphase I (Fig. I9) and anaphase I asci, there appeared to be I4 to I 5 bivalents and 28 to 30 chromosomes, respectively. This haploid chromosome number is high for the genus Peziza (Olive, 1962). Chromosome separation was asynchronous at anaphase I and the spindle fibres persisted until late anaphase. At late anaphase, the nuclear membrane appeared to break down and a semi-persistent nucleolus (Pickett-Heaps, 1970) was eliminated. Spindle-pole bodies were not discernible at anaphase I. At telophase I, the spindle was no longer visible and the chromosomes were arranged in two groups (Fig. 2I). A rod-shaped SPB was discernible on each interphase I nucleus (Fig. 22). Replication of these plaques took place before prometaphase II (Fig. 23). The plaques then separated (Fig. 24) and migrated to the metaphase II poles (Fig. 25). Metaphase II spindles were typically parallel to the long axis of the ascus; however, one (Fig. 26) or both spindles were sometimes perpendicular. Asynchronous separation of the chromosomes was common at anaphase I to III. Asynchronous anaphase movements of adjacent nuclei within an ascus are also common. The nuclei at telophase II (Fig. 27) were typically well spaced and linear in the ascus. The SPB on each interphase II nucleus (Fig. 28) replicated (Fig. 29) and then the daughters moved to the poles (Fig. 30). Although the intranuclear spindles at metaphase III were characteristically perpendicular to the long axis of the ascus, they were sometimes found oriented in any direction. Spindle-pole bodies, which were not discernible at anaphase III (Fig. 3I), were clearly visible on telophase III nuclei (Fig. 32). At interphase III, the beaked nuclear stage (Fig. 33), a SPB was situated on each nucleus and appeared to be contiguous with the nuclear membrane. The SPB of each interphase III nucleus appeared to be situated near the ascus wall. The nucleolus in each interphase III nucleus was located distal to the SPBs. The crescent-shaped SPB of each nucleus appeared to be contiguous with one end of the developing ascospore wall (Figs. 34, 36, 37). As the spore matured, the SPB was retracted from the spore wall (Figs. 35 to 36 ) and appeared as two dark-staining bodies on the nuclear membrane of each spore nucleus (Fig. 36). The SPBs were not discernible from before secondary wall deposition (Fig. 38) through to spore maturation. The mature ascus (Fig. 39) normally contained eight uninucleate, haploid spores with a number of globules situated on either side of each ascospore nucleus. On rare occasions, binucleate (Figs. 40, 4I) and trinucleate (Fig. 42) ascospores were observed. Asci with polymorphic, aberrant ascospores (Fig. 43) were also sometimes observed.

Unlabelled arrows are used to locate the spindle-pole bodies. Lengths of scale bars are approximate.

Fig. 38. Ascus with eight uninucleate spores prior to secondary wall deposition.

Fig. 39. Mature ascus with eight uninucleate spores with a number of dark-staining globules situated on either side of each unstained spore nucleus. Mounted in Melzer's IKI (I : I).

Fig. 40. Ascus with two binucleate and four uninucleate ascospores.

Fig. 4I. Ascus with one aberrant, binucleate, allantoid spore and several aborted spores.

Fig. 42. Ascus with one trinucleate and five uninucleate ascospores.

Fig. 43. Ascus with polymorphic, aberrant ascospores. 


\section{DISCUSSION}

In Peziza quelepidotia, SPBs were discernible during all nuclear divisions. Very small SPBs (approx. $0.6 \mu \mathrm{m}$ ) were found at the poles of the synchronous mitosis in the crozier. Similar findings were reported for Pyronema domesticum (Hung \& Wells, 197I) where the spindle was composed of 'at least Io microtubules'. Spindle-pole bodies were not discernible at telophase in the crozier up to pachytene. At diplotene, two amorphous bodies ( $\mathrm{I}$ to $2 \mu \mathrm{m}$ in length) were contiguous with the nuclear membrane and may have been progenitors of the plaque-like SPB. Alternatively, they may have been nuclear blebs (see Fig. 13 in Beckett \& Crawford, 1970) since Wells (1970) reports that the SPB is not discernible with the light microscope in Ascobolus stercorarius at prophase. In Xylosphaera polymorpha (Schrantz, 1970; Beckett \& Crawford, 1970), the SPB appears in the electron microscope as an electron-dense body near the fusion nucleus. Beckett \& Crawford (1970) indicate that this body 'divides' at diplotene and migrates to the poles where it forms plaque-like SPBs. Ultrastructural evidence will be needed in order to determine whether this is so in $P$. quelepidotia. As in the Ascomycetes, replication of the SPBs takes place in the Basidiomycete Coprinus lagopus (Lu \& Raju, 1970; Raju \& Lu, 1970) at the diffuse diplotene stage. The replicated SPBs in Coprinus do not separate until diakinesis (Raju \& Lu, I973).

At metaphase I, the plaque-like SPBs were approximately $0.9 \mu \mathrm{m}$ long in Peziza quelepidotia and were found on each side of a distinct metaphase plate. Lu (1967) interprets the perpendicular orientation of the SPB at metaphase I as a possible transitory stage. There is some credence to this interpretation in $P$. quelepidotia since spindles perpendicular to the long axes of the ascus in anaphase and telophase I nuclei have never been observed. The intranuclear position of the meiotic apparatus is only discernible in overstained asci. Inability to discern SPBs at anaphase I may have been due to chemical changes within the plaque (i.e. depolymerization) or more probably competition with the chromatin and the nucleolus for the stain. In a closely related species (Ascobolus stercorarius), the ultrastructural integrity of the plaques at anaphase I has been demonstrated (Zickler, 1970). Replication of the plaque-like SPBs took place at prophase II and III in P. quelepidotia. Similar findings have been reported for Gelasinospora (Lu, 1967) and Ascobolus (Wells, 1970).

An apparent increase in the plaque size was discernible in Peziza from metaphase I (approx. $0.9 \mu \mathrm{m}$ ) to interphase I (approx. I.6 $\mu \mathrm{m}$ ). In addition, the plaques were seen to increase in size at metaphase III (approx. $\mathrm{r} \cdot 8 \mu \mathrm{m}$ ) and interphase III (approx. $2 \cdot 8 \mu \mathrm{m}$ ). The SPBs almost tripled in size from metaphase I to interphase III which suggests 'the synthesis of some SPB material' (Raju \& Lu, I973). The squash technique presents one problem in that measurements are only approximate because of the enlargement of the SPBs, nucleoli and chromosomes during flattening.

The Ascobolus-type plaque (sensu Zickler, 1970) at interphase III in Peziza quelepidotia appeared to be contiguous with the plasma membrane of each spore initial. An ultrastructural analysis of spore delimitation in Xylosphaera polymorpha (Beckett \& Crawford, 1970) reveals that the astral-ray complex, and not the plaque, was contiguous with the ascus vesicle. Although astral rays have never been observed in the light microscope at any state of division in $P$. quelepidotia, it is very probable that they were present during spore delimitation. The fate of the SPB-astral-ray complex in the Euascomycetidae after spore delimitation seems to be variable. In P.quelepidotia and Sordaria fimicola (Doguet, I960) the plaques appear to be retracted from the plasma membrane of the ascospores and are later discernible on the nuclear membrane of the spores. However, this observation of the behaviour of the 
SPB in the spore of $P$. quelepidotia has not been confirmed in the electron microscope. A situation similar to that in Peziza may exist in Pustularia cupularis (Schrantz, 1970) and Ascobolus stercorarius (Wells, 1970) where a plaque-like SPB is discernible on the young ascospore nucleus. A different situation is found in Podospora anserina (Zickler, 1970) and Xylosphaera polymorpha (Beckett \& Crawford, 1970) where the SPB becomes dissociated from the nuclear membrane. In $X$. polymorpha the SPB may replicate in the spore (Beckett \& Crawford, 1970), as an additional SPB is discernible on the nuclear membrane. Spindlepole bodies may possess some degree of autonomy, since Heslot (1958) demonstrated that enucleate spores contain plaques in mutants of Sordaria macrospora.

In addition to the structural changes that take place in the SPBs during ascosporogenesis within a species (Lu, 1967; Beckett \& Wilson, 1968; Beckett \& Crawford, 1970; Zickler, I970; Wells, 1970), there are reports of structural differences in the SPBs between species. Zickler (1970) and Wells (1970) found a rod-shaped SPB in Ascobolus stercorarius. In addition, rod-shaped SPBs have been reported in a number of other Euascomycetidae (Schrantz, 1970; Westergaard \& von Wettstein, 1970; Hung \& Wells, 1971). In several species of Penicillium, Laane (I970 $a, b$ ) reported a bipartite centriole (spindle-pole body). Bipolar SPBs were observed by Girbardt (1971) in Neurospora, Chaetomium and Aspergillus. The structure of these bipolar SPBs is similar to that reported for some of the Heterobasidiomycetidae (Wells, 1971; McCully \& Robinow, 1972 a, b) and Homobasidiomycetidae (Girbardt, I968, I97I ; McLaughlin, I97I ; Raju \& Lu, 1973). Raju \& Lu interpret the diglobular SPBs in the Homobasidiomycetidae as representing 'the duplicated form of the monoglobular state'.

Distinct plaque-like SPBs have evolved in the Protozoa (Acanthamoeba: Bowers \& Korn, I968; Thalassophysidae: Hollande, Cachon \& Cachon, 1969) and centric diatoms (Lithodesmium: Manton, Kowallik \& von Stosch, 1969). There is circumstantial evidence that the SPBs provide the cell with discrete loci that control the distribution of microtubules (PickettHeaps, 1969; Tilney, I97I). It is also possible that the SPBs are reservoirs of microtubule proteins that are eventually organized into microtubules by some other structure (Aist \& Williams, 1972). In addition, there is evidence to suggest that the SPBs may play an active role in nuclear migrations in fungi (Girbardt, I968; Aist \& Williams, 1972), possibly in positioning the nuclei before sporogenesis. However, further ultrastructural and complementary cytochemical studies need to be conducted on taxonomically diverse protists before functions can be attached to the multifarious SPBs and homologies be drawn.

\section{REFERENCES}

Aist, J. R. \& Williams, P. H. (1972). Ultrastructure and time course of mitosis in the fungus Fusarium oxysporum. Journal of Cell Biology 55, 368-389.

BeCKett, A. \& Crawford, R. M. (1970). Nuclear behaviour and ascospore delimitation in Xylosphaera polymorpha. Journal of General Microbiology 63, 269-280.

Beckett, A. \& Wilson, I. M. (1968). Ascus cytology of Podospora anserina. Journal of General Microbiology $53,8 \mathrm{I}-87$.

Bowers, B. \& Korn, E. D. (1968). The fine structure of Acanthamoeba castellanii. I. The trophozoite. Journal of Cell Biology 39, 95-I II.

CARr, A. J. H. \& Olive, L. S. (1958). Genetics of Sordaria fimicola. II. Cytology. American Journal of Botany 45, I42-I50.

Carroll, G. C. (1969). A study of the fine structure of ascosporogenesis in Saccobolus kerverni. Archiv für Mikrobiologie 66, $32 \mathrm{I}-339$.

Doguet, G. (1960). Contribution à l'étude du noyau du Sordaria fimicola. Revue de cytologie et de biologie végétales 22, 109-127. 
GIRBARDT, M. (I968). Ultrastructure and dynamics of the moving nucleus. Symposium of the Society for Experimental Biology 22, 249-259.

GIRBARDT, M. (I97I). Ultrastructure of the fungal nucleus. II. The kinetochore equivalent (KCE). Journal of Cell Science 2, 453-473.

HesLot, H. (1958). Contribution à l'étude cytogénétique et génétique des Sordariacées. Revue de cytologie et de biologie végétales 19 (supplement 2), $\mathrm{I}-209$.

Hollande, A., CACHON, J. \& CACHON, M. (1969). La dinomitosis atractophorienne à fuseau endonucléaire chez les Radiolaires Thalassophysidae. Comptes rendus hebdomadaire des séances de l'Académie des sciences D 269, 179-182.

HuNG, C. Y. \& WeLLS, K. (1971). Light and electron microscopic studies of crozier development in Pyronema domesticum. Journal of General Microbiology 66, 1 5-27.

LAANE, M. (1970a). Nuclear behaviour during meiosis and ascus formation in Penicillium striatum. Hereditas 65, $133-158$.

LAANE, M. (1970 b). The vegetative ultrastructure in Penicillium. Arbok for Universitetet $i$ Bergen 4, $\mathrm{I}-\mathrm{I} 6$.

Lu, B. C. (1967). The course of meiosis and centriole behaviour during the ascus development of the ascomycete Gelasinospora calospora. Chromosoma 22, 210-226.

LU, B. C. \& RAJU, N. B. (1970). Meiosis in Coprinus. II. Chromosome pairing and the lampbrush diplotene stage of meiotic prophase. Chromosoma 29, 305-316.

Manton, I., Kowallik, K. \& von Stosch, H. A. (1969). Observations on the fine structure and development of the spindle at mitosis in a marine centric diatom (Lithodesmium undulatum). II. The early meiotic stages in male gametogenesis. Journal of Cell Science 5, 271-298.

MCCully, K. E. \& RoBINow, C. F. (1972a). Meiosis in heterobasidiomycetous yeasts. I. Leucosporidium scottii (Candida scottii). Journal of Cell Science ro, 857-881.

MCCULLY, K. E. \& RoBinow, C. F. (1972 b). Meiosis in heterobasidiomycetous yeasts. II. Rhodosporidium sp. (Rhodotorula glutinis) and Aessosporon salmonicolor (Sporobolomyces salmonicolor). Journal of Cell Science II, I-31.

MCLaughuin, D.J.(197I). Centrosomes and microtubules during meiosis in the mushroom Boletus rubinellus. Journal of Cell Biology 5o, 737-745.

Ouve, L. S. (1962). Chromosome numbers: fungi. In Growth Including Reproduction and Morphological Development, pp. 33-44. Edited by P. L. Altman and D. S. Dittmer. Washington, D.C.: Federation of American Societies for Experimental Biology.

OLIve, L.S. (1965). Nuclear behaviour during meiosis. In The Fungi: An AdvancedTreatise, vol I, pp. 143-16I. Edited by G. C. Ainsworth and A. S. Sussman. New York: Academic Press.

Picketr-Heaps, J. D. (1969). The evolution of the mitotic apparatus: an attempt at comparative ultrastructural cytology in dividing plant cells. Cytobios 1, 257-280.

Pickett-Heaps, J. D. (1970). The behaviour of the nucleolus during mitosis in plants. Cytobios 6, 69-78.

RaJu, N. B. \& LU, B. C. (1970). Meiosis in Coprinus. III. Timing of meiotic events in C. lagopus (sensu Buller) Canadian Journal of Botany 48, 2183-2186.

Raju, N. B. \& Lu, B. C. (1973). Meiosis in Coprinus. IV. Morphology and behaviour of spindle pole bodies. Journal of Cell Science 12, I3I-I4I.

ReEves, F. (1967). The fine structure of ascospore formation in Pyronema domesticum. Mycologia 59, Ior 81033.

SCHRANTZ, J.P. (1970). Étude cytologique, en microscopie optique et électronique, de quelques Ascomycètes. I. Le noyau. Revue de cytologie et de biologie végétales 33, I-IO0.

Singleton, J. R. (1953). Chromosome morphology and the chromosome cycle in the ascus of Neurospora crassa. American Journal of Botany 40, 124-144.

TILNEY, L. G. (197I). Origin and continuity of microtubules. In Origin and Continuity of Cell Organelles, vol 2, pp. 222-260. Edited by J. Reinert and H. Ursprung. New York: Springer-Verlag.

Wells, K. (1970). Light and electron microscopic studies of Ascobolus stercorarius. I. Nuclear divisions in the ascus. Mycologia 62, 76I-790.

WeLLS, K. (I97I). Basidial development in Sebacina sublilacina (Tremellales). First International Mycological Congress, Exeter, I 6, p. IoI.

WestergaARd, M. \& von Wettstein, D. (1970). The nucleolar cycle in an ascomycete. Comptes rendus des travaux du Laboratoire Carlsberg 37, 195-237.

ZICKLER, D. (1967). Analysis de la méiose du champignon Discomycete Ascobolus immersus Pers. Compte rendu hebdomadaire des séances del'Académie des sciences D 265, 198-20I.

ZiCKLER, D. (1970). Division spindle and centrosomal plaques during mitosis and meiosis in some Ascomycetes. Chromosoma 3o, 287-304. 